\title{
Urban Heritage in Baghdad: Toward a Comprehensive Sustainable Framework
}

\author{
Akram J. M. Al-Akkam ${ }^{1}$ \\ ${ }^{1}$ School of Architecture, Planning and Landscape, Newcastle University, UK \\ Correspondence: Akram J. M. Al-Akkam, School of Architecture, Planning and landscape, Newcastle University, \\ UK. Tel: 44-790-891-4260. E-mail: drakramalakam@yahoo.com
}

\author{
Received: September 29, 2012 Accepted: January 9, 2013 Online Published: January 17, 2013 \\ doi:10.5539/jsd.v6n2p39 \\ URL: http://dx.doi.org/10.5539/jsd.v6n2p39
}

\begin{abstract}
Architectural heritage is the most important legacy of civilisation and through it we can readily grasp the history of nations. Architects, urban planners and policymakers are now aware that historic cities require regulatory mechanisms if they are to maintain and enhance the fabric upon which their historicity and economic vitality is based. The historic areas in Baghdad, like those in Iraq, are suffering from declining infrastructure, a deteriorating environment, a lack of modern facilities, high unemployment rates, collapsing social impact and weakness in its urban institutions. Such pressures have brought into focus the extent to which sustainable development policies can contribute to the management of change in historic areas. A central objective of this investigation is to explore how the conservation-led regeneration of historic areas in Baghdad may be carried out in a way that promotes social, economic and environmental sustainability, and the full participation of all stakeholders. To achieve the research objective, the main theme, a hypothetical comprehensive model, and a plan and action plan are proposed. The conclusions reached demonstrate that to achieve the strategy of immediate sustainable conservation-led regeneration, the government should contribute to such conservation projects and support the formation of an institutional framework.
\end{abstract}

Keywords: urban heritage, sustainability, Baghdad

\section{Introduction}

Several interesting reasons underlie the decline of traditional residential neighbourhoods in Iraq, and the derivation of examples from Baghdad. There has been rapid growth in cities as well as population, alongside the destruction caused by giving way to the motor vehicle and to other land uses. Other changes are a rise in the standard of living and the development of new quarters of the city, the drain of the native population, and unclear planning policies towards the central areas (Al-Rahmani, 1986).

Iraq's heritage is being destroyed at a disturbingly rapid rate through several destructive processes. These have been identified as: large-scale engineering works, neglect and decay, the demolition and clearance of buildings and wide areas, ill-advised restoration work, looting and vandalism, and spatial intrusion and the removal of context.

A conference on sustainable communities in Iraq (2007) defined sustainability and made a distinction between immediate and ultimate sustainability. In the case of ultimate sustainability, this must balance the needs of both the present and the future, where rebuilding must not compromise the long-term environment or self-empowerment of Iraq. Conversely, immediate sustainability should understand, and be sensitive to, the critical nature of having a transparent process and the empowerment achieved by bringing in, and bringing forth, Iraqis. Ultimate sustainability in professional planning must be shaped by the major involvement of the newly empowered Iraqis, and the conference proposed the first step as being an assessment of the current status (Awotona, 2008).

The State of Iraq Cities Report (SICR) 2006-2007 reported that the structures of historic areas have been modified, with many buildings evolving toward commercial and government use. The city has many seriously deteriorated structures without infrastructure, leading to poor internal sanitation, drainage problems and effluences (UN-HABITAT, 2006-2007). 
However, one developmental scheme was begun during 2010, when the Municipality of Baghdad approved the urban development of the Khedmyia historic area in Baghdad, which was completed by the Architectural and Planning Bureau. It presented twelve investment opportunities for modern projects in Baghdad. Yet, in spite of some of these projects being located in historic areas in Baghdad City Centre, such as the development of the streets of Haifa, Khlafaa, Omer, and the Bab Al-Sheikh area, these streets have received little attention (Baghdad Municipality, 2009).

To protect and enhance the historic Baghdad city centre, the Municipality of Baghdad (2010) introduced a plan designed by several architectural bureaus for the urban development of the historic Al Rasheed Street. The study revealed many existing problems with the historic areas, including: neglect and decay, demolition of buildings and defragmentation of the historic fabric (Baghdad Municipality, 2010). Eventually, the Union of Architectural Heritage (2010) started a campaign to rescue Baghdad's architectural heritage.

The centres of historic Rusafa and Karkh, and the religious areas of Kahdemyia and Adhamiya, possess the distinctive urban character and identity of Baghdad streets (Al-Akkam, 2011). Unfortunately, however, all these projects focused on physical aesthetics and appearance and proposed either to demolish significant parts of the historic areas or to imitate the urban development of Western countries. These studies did not deal with the local community, and tried to use the term "sustainability" as a label for propaganda and no more. These studies were vague and did not follow a clear urban policy, or take into consideration public participation.

The problems in the old heritage areas in Baghdad are different. Housing is below acceptable environmental standards, as dense occupation rates have resulted in a significant deterioration in housing units and an increasing pressure on the infrastructure, a contradiction in architectural solutions between conservative traditional fabric and contemporary urban use, and increasing numbers of new motor vehicles, which have created traffic congestion, noise, and visual pollution. However, conservation-led regeneration for compact city centres is more environmentally relevant for the urban regeneration of Baghdad city centre (Al-Akkam, 2012).

The significance of historic environments has become increasingly evident as part of urban regenerative initiatives since policymakers and urban authorities have turned to 'culture' as an instrument for urban regeneration, with urban areas seeking to use cultural policy as a strategy of urban regeneration. In addition, it is necessary to take economic measures which will make the strategies valid and realistic and which will in turn make possible the target social conditions (Pendlebury, 2002). At the same time, the difficult task for conservation initiatives is to develop strategies which not only ensure the continuing contribution of heritage to the present and the future through the thoughtful and intelligent management of change responsive to the historic environment and collective needs, but also the preservation of fundamental elements of social environments. Such strategies will lead to more equitable and sustainable solutions to the problems currently faced by the historic quarters (Ercan, 2010).

To sum up this investigation, previous studies have not provided a clear vision for dealing with the assets of urban heritage and their relationship with environmental, social and economic issues, especially in an age of such significant transformation. Therefore, this serious problem presents a challenge for academies of architecture and planning to rethink seriously sustainable solutions. Thus, a central objective of this investigation is to explore how the conservation-led regeneration of Baghdad's historic areas could be carried out in a way that promotes social, economic and environmental sustainability, as well as the full participation of all stakeholders.

\section{Literature Review}

Conservation is not backward looking. It offers sustainable solutions to the social and economic problems afflicting our cities. It stands in the vanguard of social and economic policy, capable of reversing decay by injecting new life into a familiar area (English Heritage, 1998). Concomitant with this, the historic environment creates opportunities for social interaction, education and lifelong learning, helping to deepen our understanding of the world around us; it provides jobs and generates income, bringing new life to run-down areas, and it adds a unique dimension of beauty, meaning and character to daily life (English Heritage, 2004).

To assess historic buildings, Lichfield distinguished four types of obsolescence in historic areas. These are: functional, structural, locational and developmental (Lichfield, 1968).

Regarding conservation, Worthington (1998) argues that, as it seeks to retain the continuity of a sense of place, it becomes involved with a diversity of interest and expertise to both sustain the fabric and manage the ongoing functions. Conservation is becoming part of the mainstream, and the past is becoming part of the future (Worthington, 1998). It is acknowledged that the benefits of conservation may arise from an engagement with the historic environment through both its intrinsic historic nature, as historic places which contribute to identity 
and as a place where regeneration may occur, since the historic environment provides economic opportunities for regeneration (Pendlebury et al., 2004).

By the 1990s, the recognition and definition of historic areas had changed. There was a general consensus that the historic areas are not only striking features of many towns and cities but also assets for their economic and social renaissance. Conservation as an agent of urban revival has come to represent a vital theme in the regeneration of parts of our towns and cities. In this sense, the processes of urban conservation and regeneration can be seen as mutually reinforcing. The modern concept of conservation has evolved from an initial concern with the protection and preservation of individual buildings to a broader vehicle for urban regeneration and economic development. Conservation as an agent of urban revival has come to represent a vital theme in the regeneration of parts of our towns and cities (Pearce, 1994).

The concept of regeneration requires a proper understanding of a variety of issues combined with creative approaches based on a mix of physical, economic, social, cultural and environmental initiatives, combined with a holistic approach to urban management. In this context, urban regeneration can be defined as a comprehensive and integrated vision and action which leads to the resolution of urban problems and which seeks to effect a lasting improvement on the economic, physical, social and environmental condition of an area that has been subject to dramatic change (Roberts, 2000).

The historic environment is now an essential and integral part of successful regeneration strategies because it contributes to investment speculation, sense of place, sustainability, and quality of life (Helm, 2006). By adopting a conservation-led approach to the regeneration of the historic environment, we have been able to provide a focus for additional investment and new activities, thereby strengthening the economy of our historic areas. It helps improve business confidence, the pride of local communities and the sense of place, which all help to make the historic environment so popular. Conservation-led regeneration helps to create attractive places where people want to live, work, visit, and spend their leisure time, thereby underpinning a market-led return to urban living, and a full realisation of the urban potential of our built-up areas, in accordance with sustainability principles (House of Commons, 2006).

During the last few decades in Western Europe, the task of re-using and enhancing the existing resources has been taken as central to the task of regeneration. It was accompanied by an increasing recognition of the importance of culture as an instrument of urban regeneration together with a greater commitment to the preservation of the historic environment. This new wave produced a sense of connection and synergy between regeneration and conservation efforts. The historic environment has become a key resource in the regeneration process, and the basis for generating economic growth, investment and tourism income. Historic buildings have been at the forefront of heritage-based regeneration initiatives. Conservation is changing in the face of demands for regeneration and renaissance, and growing pressures for it to be more economically flexible and socially inclusive. The recent development in terminology is the idea of sustainable conservation. The conservation of the historic environment is now a key feature of the sustainability agenda in a number of historic cities (Strange \& Whitney, 2003). Five principles are recognised to create a framework for managing change in the historic environment. These five principles are:

1) The historic environment is a shared resource;

2) Everyone should be able to participate in sustaining the historic environment;

3) Understanding the heritage value of places is vital;

4) Significant places should be managed to sustain their values; and

5) Decisions about change must be reasonable and transparent, and consistent recording and learning from decisions is essential (Drury \& McPherson, 2007).

The most important success has been the acceptance of the need to work in accordance with the environmental objectives of sustainable development. The notion of the compact city as a sustainable built form is becoming increasingly popular among policy-makers at a national and European level. In urban renewal policy, the debates about the effectiveness of large-scale reconstruction and slum clearance, as well as the argument about the retention and improvement of existing urban fabric, resulted in an increased emphasis on the renewal of older residential areas and environmental improvement. Cultural policies were considered as providing economic benefits by creating jobs associated with their administrations and promotion and associated venues such as cafes, and restaurants. Cultural interventions were then generators of economic growth rather than a by-product of it (Roberts, 2000). 
There is general and widespread support for the principles of sustainable development to underpin and shape the urban development and regeneration initiatives. The strategies and programmes for the reuse of 'brown fields' are seen as contributing to compact sustainable cities (Adams, 2004).

Views on what actually constitutes a sustainable built environment are varied. Ecological sustainability, as it is understood in terms of resource and ecosystem protection, can be quantitatively analysed with respect to the energy and mass flows in time and space within a life cycle assessment (Kohler, 1999).

However, economic sustainability is divided into investment and use costs. Instead of minimising investment costs through crossing the low-cost of building processes and products, it is preferable for a given investment to find solutions that have the highest durability and reusability. Solutions that can be repaired and used in several ways have the highest long-term resource productivity. Buildings with low-energy consumption that are easy to operate and maintain generally have low use costs. The social and cultural aspects of sustainability include comfort and health protection, and the preservation of values, which is one of the main motivations behind any conservation project (Cole, 1999).

The literature has introduced several models of development process, embracing 'equilibrium models', 'event sequence models', 'agency models', 'structure models', and later a 'structure-agency institutionalism', which is considered a subset of two main approaches: actors-institution and political-economy. Structure models focus attention on the way markets are structured, the role of capital, labour and land in the development process, and the forces which organise the relationships of the process and drive its dynamics (Healey, 1991). Also, four main approaches to modelling the development process include: sequential or descriptive approaches, behavioural or decision-making approaches, production-based approaches, and the structure of provision. Alternatively, agency models, or behavioural or decision-making approaches, focus on the roles, interests, behaviour and decisions of different actors, their inter-relationships and the impact they have on the development process (Gore \& Nicholson, 1991).

An institutional model of the development process was proposed as a universal model to address the agencies, events, and diversity of processes in different conditions. The model focuses on the empirical links between structure and agency through relating the construction of roles, and the strategies and interests of agencies, to the material resources, institutional rules and organising ideas which agents acknowledge implicitly and explicitly in what they do (Healey, 1990). However, the 'structure-agency model' promises to achieve extensive coverage. It considers the complexity of the events and agencies involved in the process and the diversity the process may take under different conditions (Healey, 1992).

It is necessary to identify key actors, their aspirations and objectives, their relationships relative to each other, and their motivation for involvement in the development process. The actors identify the development process based on their motivations into two major groups: 'demand side' development actors, including investors, occupiers, public sectors, adjacent landowners and the general public, and 'supply side' development actors, including landowners, developers, funders, builders and advisers (Carmona et al., 2003).

\section{A Case Study}

\subsection{Recent Urban History and Transformation}

Four themes have been identified that introduce major stages of transformation in the historic areas of Baghdad.

The first theme is large-scale destruction. Since World War I, Rusafa, the largest of Baghdad's historic cores, has lost nearly twenty-five per cent of its historic fabric by official demolition for new roads and clearance programmes alone. The first is Rashid Street, which was begun by the Turks in 1915 but completed by the British in 1918. It is forty metres wide, including ten metres of commercial development on either side. It is almost 3.8 kilometres in length. The second is Kifah Street, which was driven through Rusafa in 1936. Its width is fifty metres, which includes fifteen metres for commercial development on either side, while its length is about 3.2 kilometres; this caused serious damage to a great area of Rusafa. The third is Jumhouriya Street, which was cut through the entire length of Rusafa in 1954. The Development Board envisaged developing an American-style commercial street flanked by high-rise office blocks. It was implemented at a width of eighty metres, which includes twenty-five metres for development on both sides, and a 3.7 kilometre length cut across almost every neighbourhood, or mahalla, in Rusafa. It destroyed an area of about one third of a million square metres, including some 1,500 traditional houses and more than fifteen mosques (Ihsan Fethi, 1977).

Another major destruction in Karkh was caused in the late 1960s by the construction of Haifa Street. This new east-west axis street has a length of 2.3 kilometres and a cross section of 29 metres that excludes the development areas on both sides (Al-Rahmani, 1986). 
The second theme is related to the urban planning of Baghdad. Within less than ten years (1956-65), three firms from three different western countries were called to prepare a master plan for Baghdad: Minoprio, Spencely and Macfarlane (U.K.) in 1956, Doxiadis Associates (Greece) in 1958, and Polservice (Poland) in 1965. Yet, in every case, the important conservation questions regarding the city's heritage were either totally ignored or, at best, superficially considered (Ihsan Fethi, 1977).

Both master plans, one prepared by Minoprio and Partners and the other by Doxiadis Associates, not only ignored the concerns of conservation but positively advocated the total demolition of Baghdad's historic areas. The following statement is quoted from the report of Minoprio's plan (Mimoprio, Spencely, \& Macfarlane, 1956):

The old, central areas of Rusafa and Karkh, together with the smaller areas of Adhamiya and Kadhimiya, largely comprise a dense mass of congested buildings, intersected by narrow, winding alleys. They are without any open space or other amenities. These areas should be demolished and comprehensive layouts prepared for their development.

Doxiadis' plan was more alien in concept than its predecessor. The overall approach of the planners to the historic cores was that of redevelopment and renewal rather than conservation. In general, they believed that the old quarters were destined for destruction and replacement by modern structures, and that only groups or individual buildings particularly worthy of preservation should be selected (Doxiadis, 1971).

In relative terms, the Polish planners were more aware of Baghdad's heritage than their predecessors. Their Master Plan for Baghdad for the year 2000, however, did not propose the creation of conservation areas in Rusafa, Karkh and Aadhamiya. However, the plan for Kadhimiya represented a hopeful development.

According to the political demands of the 1970s, many municipal authorities in Iraq adopted the rather unfortunate policy of 'freeing' important historic religious buildings from their surroundings. Apart from the fact that some of these surroundings may be historically or architecturally important in themselves, their demolition represents a loss authenticity in terms of setting and urban context. Examples of such losses are the clearances surrounding the shrines of Kadhimiya, Karbala, and Najaf (Ihsan Fethi, 1977).

The third theme, of the wars and sanctions against Iraq (1980-2003), prompted additional serious decline and deterioration of the historic areas. The eight-year war with Iran (1980-1988) was marked by major social and economic change. The war diverted much of the resources to war-related projects, where immigration from rural areas, and immense population growth, contributed to the rapid and physical expansion of the cities, creating a dramatic and chaotic situation. These factors influenced the process of urban development in general and led to the further decline of historic areas in particular. However, international consultants were consulted in 1980 to prepare studies on the conservation and rehabilitation of two areas in Baghdad. Both of these studies were concerned with the shrine areas of Kaylani in Rusafa and Kadhimyia that were disconnected from their surrounding urban fabric in the early 1970s. The shrine of Kadhimyia still stands alone in an area of vacant land surrounded by half-amputated traditional houses. Unfortunately, only theoretical studies were available and no tangible or successful project has taken place (Al-Rahmani, 1986). However, the Baghdad Municipality has conserved a number of individual traditional buildings since 1980. Unfortunately, this significant achievement focused on aesthetic conservation only.

The sanctions against Iraq (1990-2003) increased the problem of urban development in historic areas and led to the severe decay of the historic urban fabric. Most new religious buildings and services such as public baths and water reservoirs were built by private individuals, usually wealthy merchants. During the sanction period, the comprehensive development of Baghdad for 2015, completed by an Iraqi team, referred to many problems facing the architectural heritage in Baghdad. It documented heritage housing below acceptable environmental standards, suffering from rates of intensity and occupation, and resulting in significant deterioration of the housing units and pressure on infrastructure. Moreover, in addition to the problems of traffic congestion, noise, and visual pollution, there was a lack of investment and capital in these areas because of the high costs required to develop and adapt the conservation of heritage buildings in historical areas (Municipality of Baghdad, 2003).

The fourth theme is of the post-sanction period (2003-present), which is characterised by the changes in the formal distribution of political power, economic reform, and the unclear vision of economic, social policies. Accordingly, the historic areas in Baghdad did not obtain any tangible international assistance, including that for the development of infrastructure. 


\subsection{Description of Historic Areas in Baghdad}

The capital, Baghdad, is a large metropolitan city of 6.77 million people. It is located on both sides of the river Tigris. Architecturally, there are different patterns: traditional pre-1918 ones of vernacular design which destroyed urban heritage; colonial patterns from the 1920s British occupation, and later modern types. Moreover, there are also different building types such as: houses, mosques, tombs, commercial storage or khans, traditional markets or suqs, public hot baths or hammams, churches, schools, shops and cafes.

Baghdad possesses distinctive cultural patrimony, which is historically and religiously concentrated mostly in the heart of the city centre on both sides of the Tigris River in the area between Bab Al-Mudtham bridge in the north and Al-Jumhoria to the south, and between Ghazi Street to the east and Haifa Street to the west, with a high concentration in the Rusafa. The urban fabric of the traditional areas characterised by the old fabric is generally organic and compact, narrow footpaths and lower skylines (1-2 stories). It is also distinguished by its facades, methods of layout and building materials. It contains a large number of old buildings and small houses. The land use of the traditional areas is residential, commercial, industrial, and for public services.

The modern city of Baghdad contains four areas of historic or architectural interest: Rusafa, Karkh, Aadhamiya and Kadhimiya. In all, they cover some six square kilometres and consist of seventy-five traditional neighbourhoods. They are surrounded by modern urban growth, and physically well-defined by their characteristic urban fabric and by the roads which have replaced their old walls. These historic cores are essentially the urban expression of a past traditional age (Ihsan Fethi, 1977). Figure 1 shows the existing historic area in a general plan of Baghdad city, Figure 2 shows the existing historic areas in Baghdad, and Figure 3 shows the existing historic areas in the Baghdad City Centre.

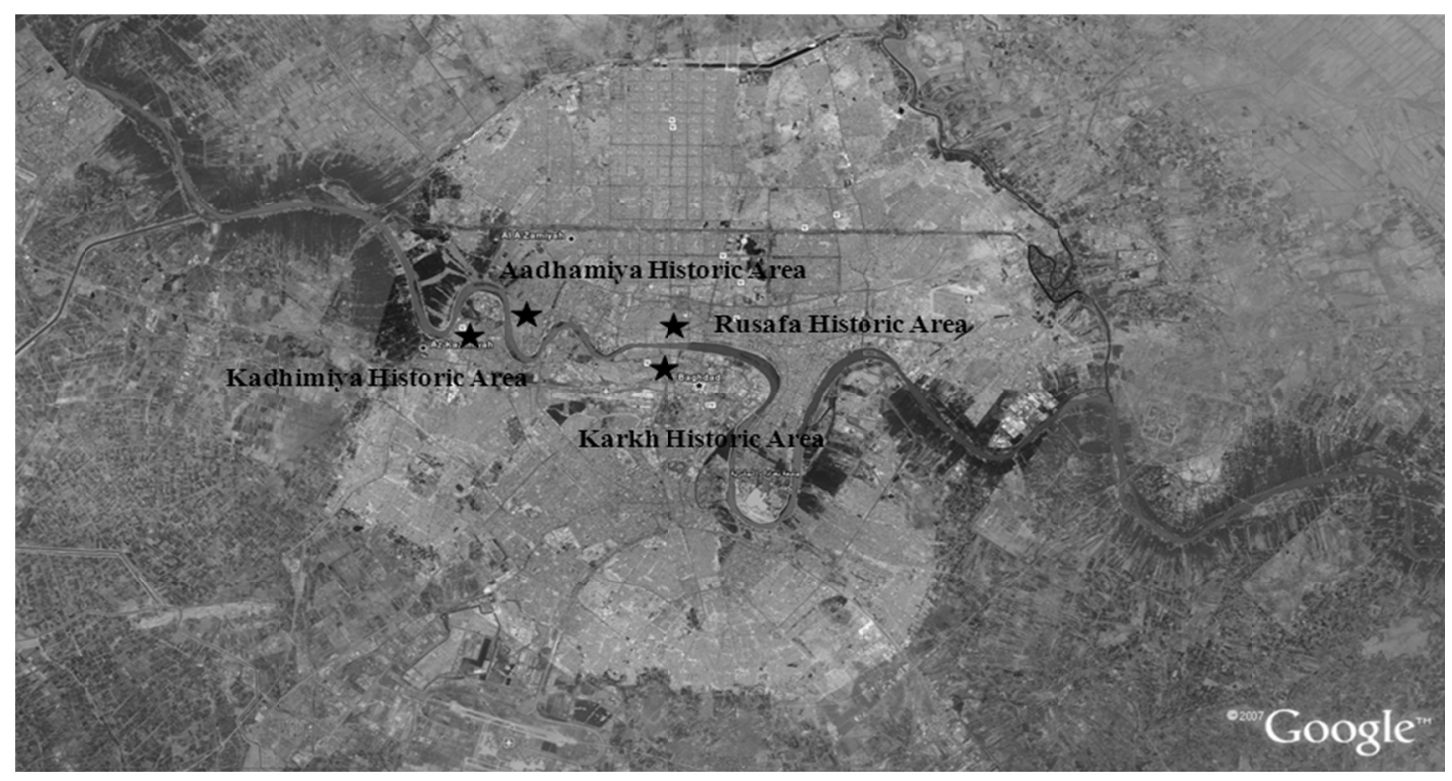

Figure 1. Existing historic area in a general plan of Baghdad city 


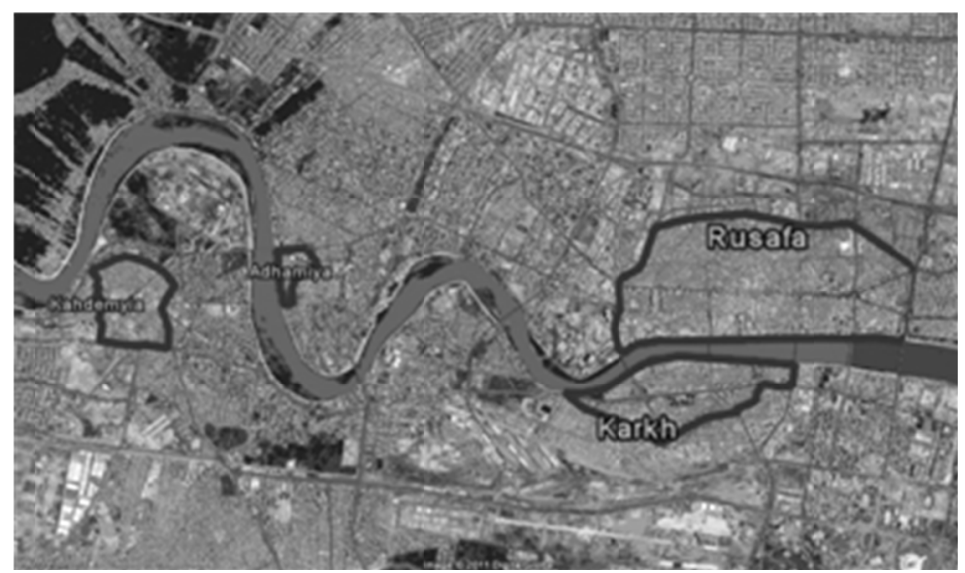

Figure 2. The existing historic area in Baghdad

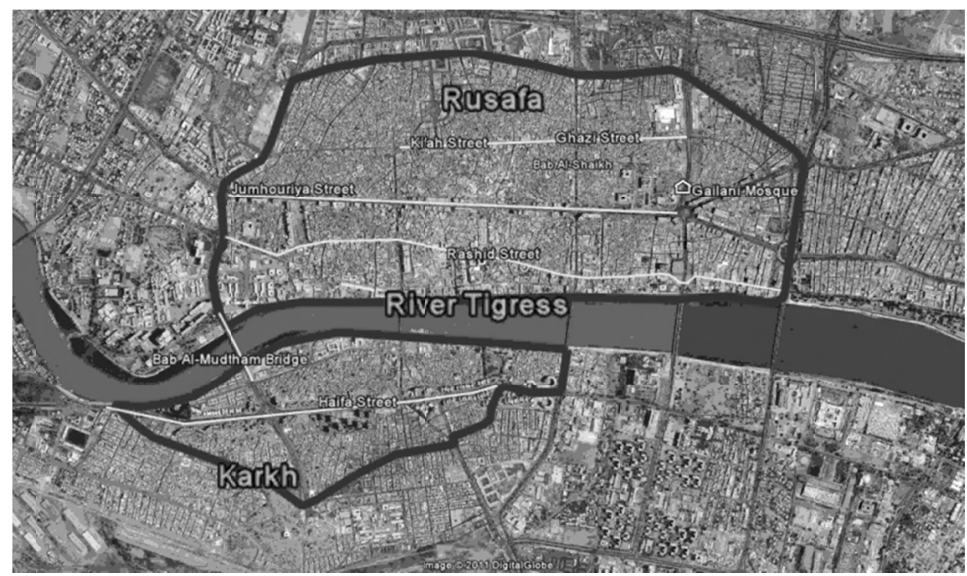

Figure 3. The existing historic area in Baghdad city centre

The first largest historic area of Rusafa is about 360 hectares in area. It is roughly rectangular in form, with its three kilometre-long south western side bordering the Tigris. The Bab Al-Shaikh bridge, which was probably in existence before the late twelfth century, and the Gailani Mosque, were the most important urban features in Rusafa. A typical neighbourhood ranges between three and twelve hectares. The average percentage of building coverage -mainly by courtyard houses -reaches some eighty-eight per cent, but twenty-four per cent of this is in fact 'open space' represented by open private courtyards, with the remaining twelve per cent taken up by pedestrian alleyways.

The second historic area of Karkh is situated opposite Rusafa on the western side of the Tigris, and is what remains of the oldest parts of Baghdad. It is roughly triangular in form, covering an area of about eighty-five hectares, and consists of fourteen neighbourhoods of cultural interest. Its riverfront is about two kilometres long and is largely occupied by traditional houses, which occasionally project over the river, giving it a unique character.

The third historic area of Aadhamiya at about twenty hectares consists of four traditional neighbourhoods, all clustered around the main mosque of Abo Hannifha. The historic fabric that remains of interest today is only about twenty hectares. The large-scale destruction in the Aadhamiya historic area was caused by the modern development that has taken place within and around it since the early 1940s.

Kadhimiya, the fourth historic core of Baghdad at about 58.59 hectares, is more preserved than the others. Kadhimiya derives its name from the shrine of Imam Musa Al-Kadhim, the revered Shi'a descendant of the Prophet who died and was buried there in 800 AD. Its existing core is typical of all shrine-cities in Iraq, such as Samarra, Karbala and Najaf. It is roughly circular in form, about one kilometre in diameter, with the shrine occupying its centre and dominating its functional and social life, as well as being one of the finest in Islam. The area consists of four traditional neighbourhoods: Shiyoukh, which is the largest, Tell, Dabagh Khana, and Qatana, 
important markets such as Astarabadi Suq, and many large commercial storage buildings or khans (Polservice, 1974). Figure 4 shows the existing historic areas in Kadhimiya.
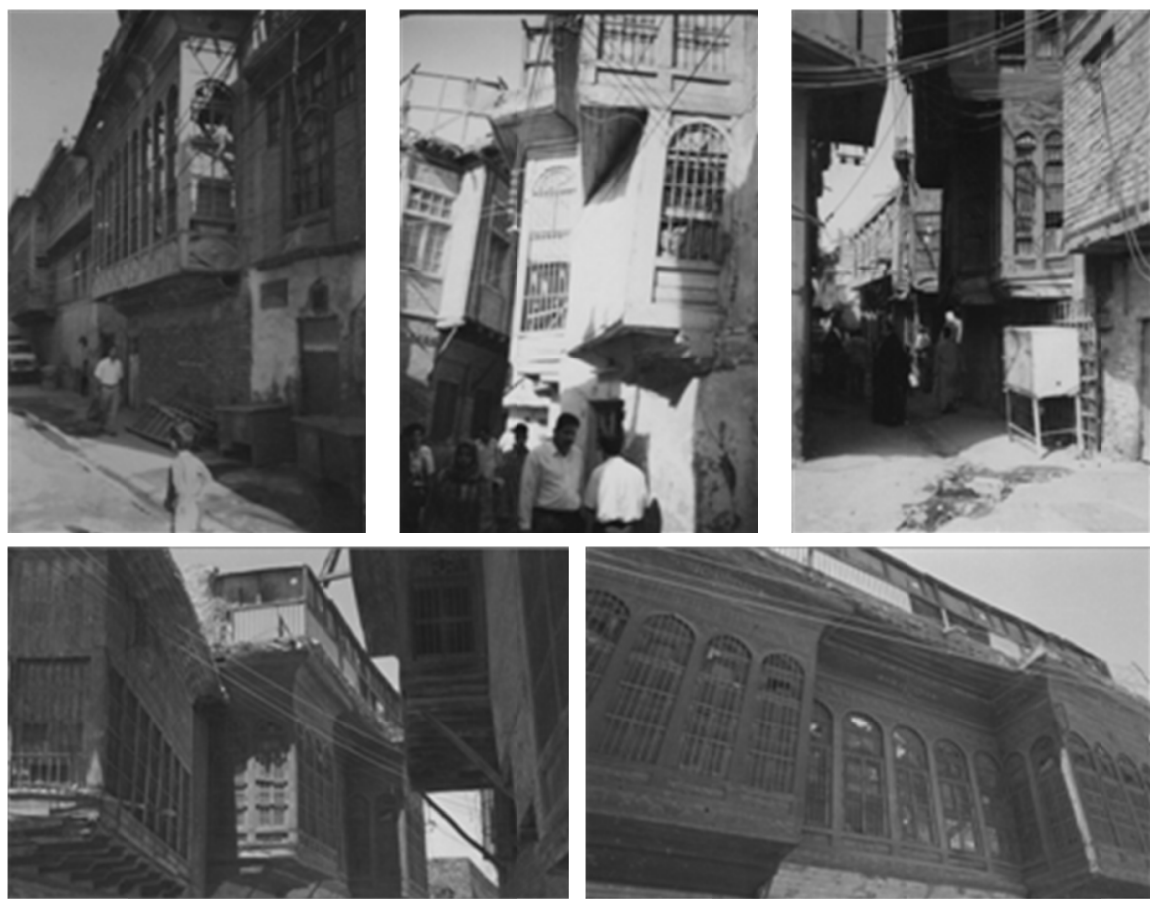

Figure 4. The existing historic area in Kadhimiya

The traditional neighbourhoods are characterised by upper floors which project over narrow footpaths. The benefit of the projections and the narrow footpaths is to create shade and keep the place cool in the harsh climatic conditions, especially in summer. A highly compacted urban pattern and population density is due to smaller plots averaging 50-150 sq. metres (Al-Rahmani, 1986).

The borders of a neighbourhood are no longer physically clear, nor are they easily recognised by any identifiable boundary or pattern as their old walls have long been demolished. The names are often derived from their past ethnic and religious structure, their tribal affiliations, a mosque or a tomb, or the type of work associated with a particular neighbourhood. Individual alleyways are often named in the same way. The traditional houses in Baghdad are planned around a central open courtyard. The courtyard represents the focal element and its use has been effectively employed over the past several millennia. An overarching consideration in the design of such houses was privacy, which evolved as a response to the severely hot and dry climatic conditions. However, the traditional markets called suqs fall into three main types: covered, open, and open market square, or maidan. The first type is usually consciously designed and permanent (Polservice, 1974).

\subsection{General Problems}

Generally, the historic areas in Baghdad are faced by enormous backlogs in infrastructure and services and are confronted with increasingly overcrowded transportation systems, insufficient water supply, and deteriorating sanitation and environmental pollution. The four types of functional, structural, locational and developmental obsolescence are also relevant to the context of historic areas. The historic structures are suffering from continued deterioration through physical decay, inadequate maintenance, serious problems of land ownership, the difficult conditions of the historic areas for construction, a lack of documentation of heritage, general critical shortage of qualified staff and technical specialists in conservation, an absence of available funds for conservation work, growing unemployment, and social conflict. All these factors represent the phenomenon of the rejection of living in such a traditional environment.

There has been a tendency towards excessive involvement of the central government reflected by the predominance of a top-down approach to the whole conservation or development process, with bottom-up approaches being completely absent. Figure 5 shows examples of deterioration in the historic areas. 

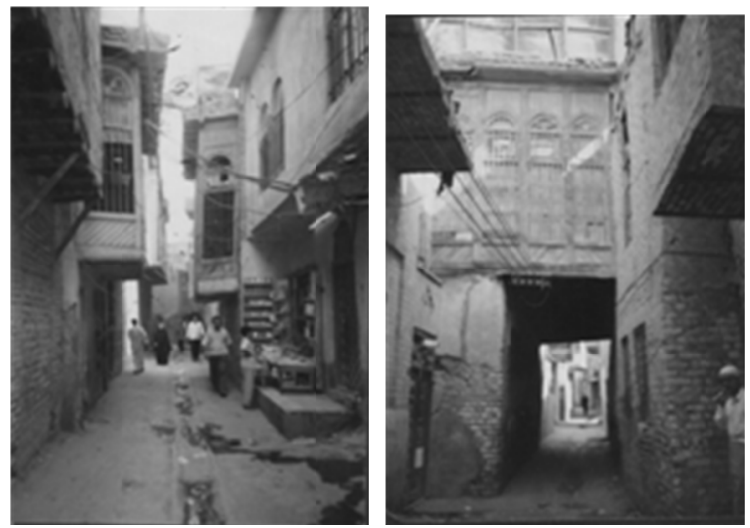

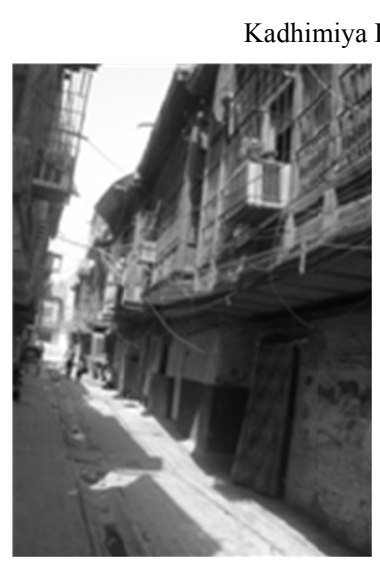

Karkh historic area

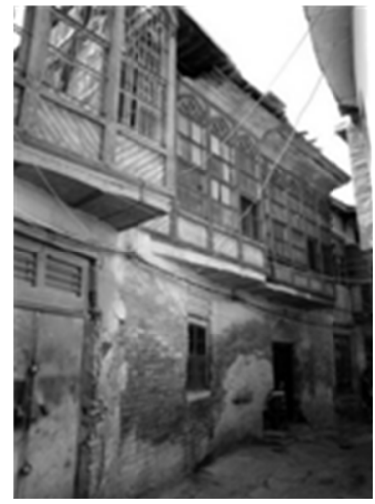

Rusafa historic area

Figure 5. Examples of deteriorated historic areas in Baghdad

\subsection{Historic Areas and the Development Plan of Baghdad}

As a response to the purpose of possible integral urban rehabilitation, the development strategies of the "Comprehensive Development Plan of Baghdad 2000", achieved by Polservise consulting engineers, should be discussed. Their Master Plan of Baghdad for the year 2000, however, does not propose the creation of conservation areas in Rusafa, Karkh and Aadhamiya. In fact, their detailed plans for the redevelopment of several blocks in central Rusafa show a 'planned' attempt to change substantially the historic character of these areas. This redevelopment may involve the wholesale demolition of one of the most interesting historic parts of the city. Even if the buildings of outstanding cultural interest in the area were to be left standing, the removal of their urban context would represent a serious loss of their authentic setting. Any comprehensive redevelopment of the historic cores which accepts that the important buildings should be preserved must be preceded by a carefully conducted conservation survey. However, no such survey was undertaken as the company was paid to prepare a conservation survey for Kadhimiya alone and not for other historic cores. Because of its relatively well-preserved fabric, Kadhimiya was chosen for 'redevelopment and preservation'. According to Polservice, the main objective of the study was to "formulate guidelines for the redevelopment of the area and to establish the policy of the conservation of buildings of historical and traditional artistic value" (Ihsan Fethi, 1977).

The historic Rusafa and Karkh areas are designated as the future "Central Business District" (CBD) according to the Comprehensive Development Plan of Baghdad 2000. These historic areas would be radically affected by the proximity and overemphasis of the other functions and increase in value. This would naturally affect the relationships and character of land distribution, land use, type of construction, and infrastructure. In comparing the present land use of Rusafa and Karkh with the CBD proposal, the historic areas will be confronted with the social problems accompanying this transformation. The concept of inner city in the "Comprehensive Plan 2000" stands in contrast to a polycentric city model suggested for Baghdad. In such a model, the inner city area would be differentiated as follows: the inner city would have two types of centre: the "city centre" and the "town centre". The city centre consists of a CBD with sub centres; the "town centre" is further subdivided into district centres and community centres. The suggestion is basically that of urban hierarchy with each level having 
specific functional roles. The smallest unit in the hierarchy would be historic neighbourhoods consisting of a concentration of residential spaces, facilities for day life, and neighbourhood services. It would offer more attracting living conditions through reduced density, improved living space, and full community services. One of the basic features of urban structure is the maintenance of balance between past and future. Since the old city of Baghdad suffered a great deal of destruction, one strategy should be adopted now to save the last four historical areas of the city. Historical elements like traditional markets/ "suqs," public baths/ "hammams" and houses should be integrated into the redevelopment plans. The importance of Aadhamiya and Kahdimiya lies in their mayor religious and cultural position, as charcterised by their shrines, mosques and minarets, while the Rusafa and Karkh areas are more important as commercial and residential areas. Even today, a number of historic coffee shops and particularly the old central "Suqs" and "Khana" are still functioning. All historic areas have retained their urban pattern. The Comprehensive Development Plan for the year 2000 proposes to preserve parts of these areas and to adopt other functions and activities. However, an environmental impact assessment of the current physical environment should be conducted (Baghdad Municipality, 1982).

\subsection{Potentialities and Constraints}

The aim of this section is to present environmental, social, economic and institutional aspects. In order to specify possibilities and constraints, the use of the wealth of available written 'grey' material, e.g., university theses, consultancy reports and, where possible, qualitative surveys based on photographs, are relied on.

Environmentally, the microclimate and compact urban form may provide an intimate understanding of the historic areas. The natural environment of the Tigris River, where three of the historic areas, Rusafa, Karkh and Aadhamiya, are located, includes a number of monumental buildings, mosques, and traditional markets plus some private housing units. The riverfront is continuous but is divided into separate areas of various architectural features. However, these historic areas have failed to integrate the scene at the riverfront with the general urban fabric in the centre, because of the lack of openness toward the river. Figure 6 shows the riverfront in Rusafa.

Because Rusafa still functions as the centre for the whole of Baghdad, its historic fabric has been under tremendous pressure from modern development and has consequently suffered the worst losses compared with the other three cores. However, there is still a rare but brief opportunity to stop further destruction and conserve historic unique areas as there is the potential to reuse, adapt or extend an existing structure. Rusafa possesses many historic buildings that have already been conserved, such as the Al-Mustansyria school, the Bahghdadi Museum and Khan Merjan, in addition to other significant features such as the historic Rashid Street, the historic castle which is used as the Ministry of Defence, and many tombs, mosques, houses, cafes and squares. Figure 7 shows some of the conserved historic buildings in Rusafa.

Although the historic areas are still identified by their traditional character and architectural values, the traditional elements have tended to become more obsolete. There was a rapid depreciation of property accompanied by physical and functional obsolescence. The Holy Shrine in Kadhimiya has become almost totally isolated from its historic urban context and the historic fabric around the shrine has been neglected, is decaying, and will eventually be destroyed. Figure 8 shows the Kadhimiya Shrine.

To assess the historic values, three grades were proposed by Polservice to classify the cultural interest of traditional buildings within the area of old Kadhimiya, and four yardsticks were suggested (Polservice, 1974). Unfortunately, the previous proposal dealt with aesthetic values and no alternative has yet been introduced to assess complete traditional neighbourhoods.

During the past military conflict, the missiles that were fired and the strong explosions that occurred at the fall of Baghdad in 2003 and after have especially affected the historical areas of Rusafa and Karkh, which are close to the previous presidential palace (the Green Zone) and caused severe damage. Moreover, the wave of car and bomb explosions caused by terrorism in the area of the Kadhimiya Shrine and Aadhamiya mosque, and other acts of violence, caused the walls and the foundations of the heritage houses to crack and accelerated the collapse of some of these houses. Because the residential houses are in poor repair, many of them are in danger of collapsing and thus causing the death of numerous families; people have started to be careful and so they have already demolished those heritage houses which might fall down. Movement in general has become more difficult and complicated because of the checkpoints, traffic jams, and explosions, and it has become a familiar occurrence to change vehicle and pedestrian routes in order to guarantee safety. Because of the curfew, the residents generally change their routes at night time in order to reach their destinations. 


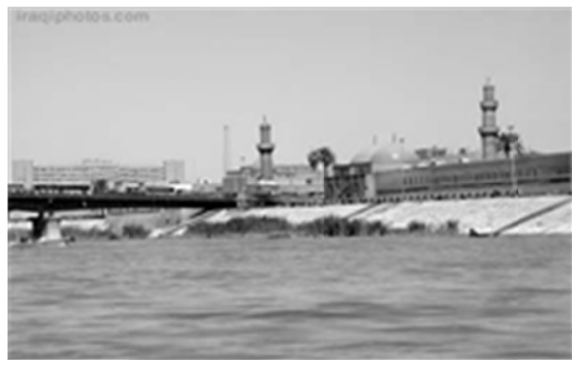

Al Suhadda Bridge

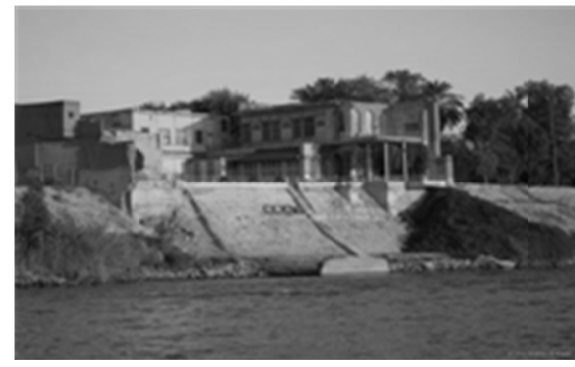

Shaashoaa Palace

Figure 6. River front in the historic area in the Baghdad city centre

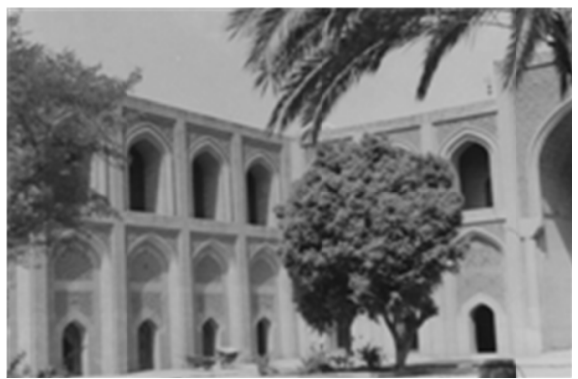

Al-Mustansyria school

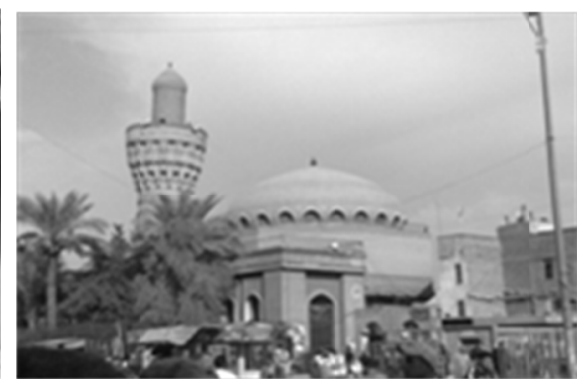

Al Kulafaa Mosque

Figure 7. Examples of conserved historic buildings in Rusafa
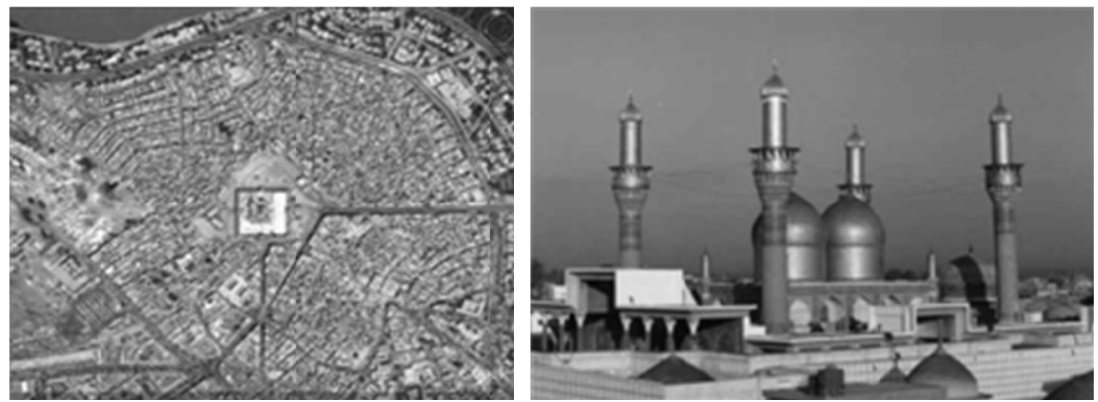

Figure 8. Kadhimiya Shrine

Socially, nowadays there is a tendency to return to traditional values and past traditions and there has been a promotion of the notion of identity. The historic areas are characterised by the original social structure and the significant role of culture, religion and habits, and are representative of social cohesion. The social structure of the inhabitants is constructed according to family, household, tribe, relationships, roles, and institutions. Social values, conventions and arbitrariness can be distinguished, as well as trends, attitudes and unique types of ceremonies for births, circumcisions, fasting, weddings, and deaths. It is interesting to note that although this area is socially and physically depressed, it still acts as a continuous source of cultural inspiration for citizens. Many people prefer to return to the historic areas to attend mosques in the neighbourhoods in which many of them grew up. Various religious activities, especially ritual ceremonies, are still adhered to by inhabitants. The vitality of festivals and rituals in these areas is mainly rooted in the religious belief of the society. Also, there were gatherings on the river banks both in the evenings and to make use of the shade. The cafes located on the river banks were main areas for meeting. In the afternoon, people and families used to bring a number of mats and lay them on the ground in an oblong shape, then sit down and chat. The river banks were green at those times, but now all these activities have stopped. The river has also been used to soothe the high temperatures in summer when women used to throw water on their bodies. There has been an increasing difficulty in environmental adjustment to both the cold and hot weather due to the use of modern air-conditioning devices in homes. There is difficulty in reviving the old way of life because the standards have changed and the region has lost its original inhabitants. Such collective ritual activities convey an intimate sense of belonging to these areas. 
Generally, the traditional neighbourhoods in Baghdad are characterised by limited income or occupied by the poorest groups of society, and the native population is gradually being replaced by rural immigrants. The historic areas are susceptible to an increasing crime rate, violence and, sometimes, terrorism. The spatial changes and transformation in the historic areas has been accompanied by social fragmentation, poverty and a breakdown in social organisation. Eventually, even though these areas have religious representatives who would normally play a more powerful role than the official administrative body in such areas, the inhabitants have generally been excluded from participating and cooperating in decisions and policy-making.

Economically, some of the historic areas have strong bases, such as Rusafa, which acts as the commercial centre of Baghdad and Kadhimiya, and which possesses dominant religious activity; in contrast, Karkh is distinguished by relatively less activity. Finally, Aadhmyia seems to be characterised by religious rather than economic activity. Generally, there are many famous commercial markets, or suqs, in Rusafa, for example Shorja Suq which has a national role. Baghdad's traditional markets today still show the characteristic division of trades, goods, and crafts. Each suq, or group of suqs, occupies a certain location that is often interrelated with its adjacent suqs because of functional connections. For instance, Sarai Suq, which specialises in books and stationery, is located next to Mutanabi Street, which specialises in print works and stationery storage. Similarly, the Sarafin Suq that is occupied by moneylenders and exchangers is now conveniently situated near a modern street of banks. Figure 9 shows traditional markets, "suqs".

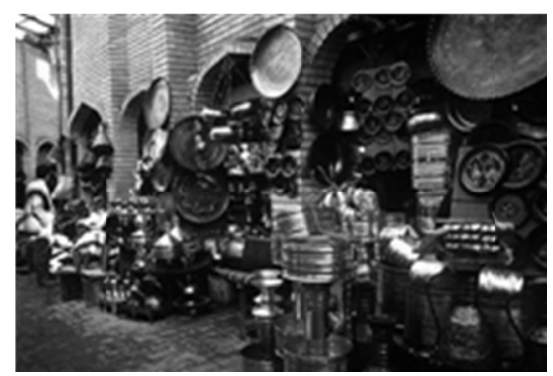

Safafer suq in Rusafa (Conserved building)

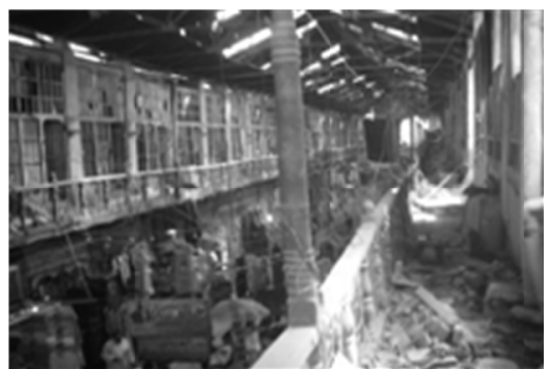

Asterbadi suq in Kadhimiya

Figure 9. Traditional markets: suqs in two historic areas

However, the challenges of a national economy which has suffered from wars and sanctions are unemployment, no access to sufficient investment, especially private investment, and insufficient official promotion of public interest in conservation. Moreover, the price of land near and around the commercial land use has increased remarkably and the type of materials and high standards of craftsmanship required for conservation and restoration are usually very expensive. The residents of historic areas are predominately craftsmen who produce for their quarter or for rural customers. Another large group are the businessmen who deal with different activities. Manufacturing and small industry are well represented in historic areas. The four main industries in the dominant historic areas are: furniture, car repair, metalworking, and textiles. In spite of the slight improvement of the economic situation of the inhabitants after 2003, the weak economic situation of the majority of inhabitants is still obvious. Migration, without special investment in heritage areas, has continued.

Institutionally, the responsibility of the protection of historic areas can be divided into five broad agencies: the directorate of antiquities; town and country planning carried out by the Municipality for Baghdad, and by the Ministry of Municipalities and General Works for the rest of Iraq; religious affairs administration; tourism administration, and research and education. Conservation ought to improve living conditions for ordinary people. That is why housing has been the centre of attention in all successful conservation work. The implementation of previous plans was by the authoritarian government, but the most critical problem is how to finance such a plan, which might involve a straightforward housing subsidy from the local or central government, or a combination of the two. There is no doubt that international organizations may play a major part in awakening interest in conservation, and indeed one of the lessons of the cultural aspects is that conservation in areas where the very poorest people live must be worked into a broader economic and social policy. But, unfortunately, the central government still exercises a strong influence over local authorities and retains a tight hold over all urban development affairs. The institutional fragmentation and lack of coordination between the various protective actors has decreased the efficiency of the efforts to conserve the historic environment. In addition to financial corruption, the lack of transparency and accountability of some government actors, and inadequate legislation, a 
lack of legal enforcement is associated as a significant factor. One of the overriding influences is at the policy-making level, where the application of priorities, based on the experience of developed countries, has led to a misunderstanding of the urbanisation process in historic areas. Finally, urban planners and architects prefer to impose the subjective perspective under the label of modernisation and to continue to demolish historic areas by imposing modern skeleton maps and zoning ordinances on the development schemes, like those which have already been proposed for the Kadhimyia historic core.

\section{Proposed Plan}

\subsection{Main Theme}

A conservation-led regeneration agenda should focus upon the support of economic, social, environmental and institutional development in a sustainable way. The purpose of this plan is to meet the needs of the local community while respecting its cultural values. The local architecture discourse has responded to the gathering of the social structure around religious power and doctrinal authority, environmental challenges and cultural connotations. It relies on the vocabulary of unity, homogeneity, compactness, simplicity and harmony. Therefore, the departure point proposes to look at the historic areas as a 'holy constant'. They should emerge from these places and community needs and aspirations within a cultural frame. The local community should build a significant partnership, especially with academic planners and architects, based on cooperation first, then extend this partnership to other actors based on shared interests, joint understanding and action.

\subsection{Setting Objectives}

The aim of this plan is to respond to multidisciplinary issues that are composed of social, economic, environmental and institutional perspectives. The objectives of the social plan are to sustain cultural continuity by maintaining the original social pattern, structure, traditions and activities, and to meet the daily needs of existing inhabitants. It is certain that the revitalisation and promotion of the cultural activities and religious ceremonies could play a key role in the animation of the community and foster a sense of belonging among the inhabitants.

In an economic sense, the important question which arises is the feasibility of a conservation-led regeneration process. How should the historic areas focus on promoting economic growth and increasing profitability and productivity? To shape the economy of historic areas, the objectives of the plan are identified as follows:

- the articulation of a strong vision for the kind of economy that the local community, supported by experts, is seeking to develop in the historic areas;

- the promotion of a greater degree of economic vitality and viability of conservation, while also offering new employment opportunities;

- the proposal of a coherent policy agenda and spatial framework within which central government and other stakeholders can take decisions about strategic investment;

- the provision of a clear evidence base for strategic planning and local decision-making within and between local partnerships, including attracting investment in the historic urban areas.

The key sustainable objectives of the environmental plan are to conserve the historic urban pattern, spines and characteristics of urban form and typology. Also, it is necessary to maintain the quality of the historic environment by contributing to quality of life by eliminating and preventing the spread of blight and deterioration, improving infrastructures and enhancing amenities and the urban scene.

The objectives of the institutional plan are to achieve the successful formation of an institutional framework, and to develop planning and legislation.

\subsection{Building Hypothetical Models}

The proposed model introduces a framework for sustainable conservation-led regeneration. According to the model, the existing historic areas represent the major sustainable resources of social, cultural, environmental -including physical -economic and institutional issues.

The protection of the community structure, health, comfort, behaviours, activities, traditions, and values are the priority of cultural and social issues, while the protection of the local ecosystem and resources are the priority of environmentalists. Meanwhile, lower costs, including reuse and long-term recourse productivity, are the significant elements of the economic issue. Finally, the interest, behaviour, role, and decisions are correlated mainly to the institutional issues. In this respect, the model adds the local community as a stakeholder in addition 
to a number of others, such as social, religious and economic stakeholders, the municipal council, and investors, planners, architects and developers.

Authority and leadership should be governed by an independent institution, whereby academic planners and architects are likely to take a significant role in such a complicated process.

In order to reach a comprehensive state, the bottom-up model should integrate with a top-down model in the process of developing Baghdad. Figure 10 shows the proposed model.

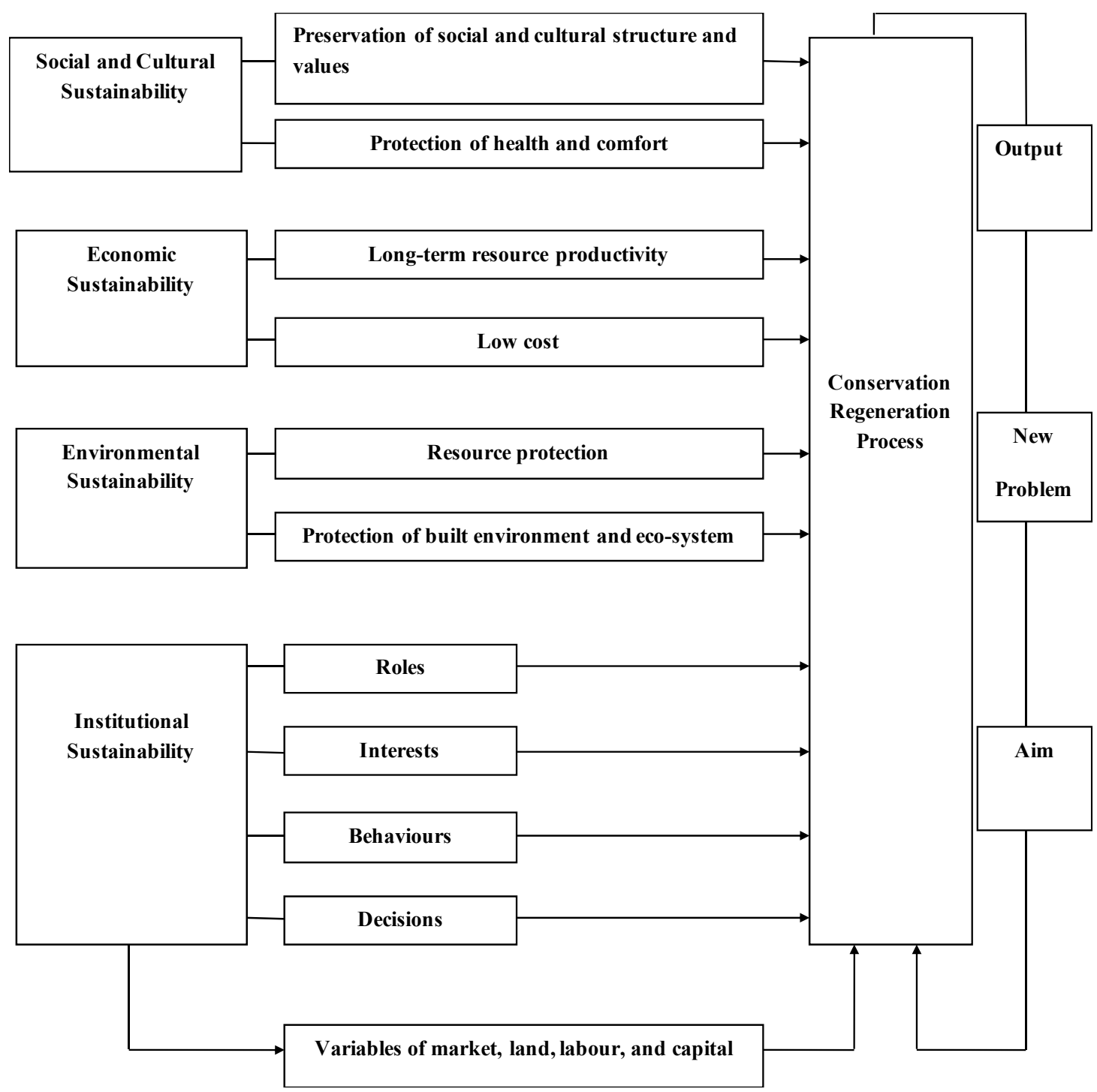

Figure 10. Sustainable framework for urban conservation

\subsection{Comprehensive Plan}

\subsubsection{Core Plan}

The plan has the following components:

1) Economic: investment, private businesses and other social services. The central government, international organizations, and both public and private capital should cooperate to fund urban renewal.

2) Social: human capital services such as health and education facilities.

3) Environmental: infrastructure and the built environment. 
4) Institutional structures of society: management and governance aspects of the community - the mayor's office, development agencies, governing councils and the local community.

\subsubsection{Action Plan}

The following stages are proposed for regenerating historic areas:

- immediately stop any demolition in historic areas, as suggested by consultant bureaux in cooperation with Baghdad Mayoralty after 2003.

- establish an independent 'Urban Heritage Council for Historic Areas' led by academic planners and architects and include different actors. The government should support this council financially and give a more independent role to local municipal councils. Direct dialogue between different actors may provide a new opportunity for partnership-based policymaking.

- assess and re-evaluate the existing status of historic areas, community, budget and capital, and environment including physical ones by experts.

- establish a strategy and programme for sustainable conservation-led regeneration and a time line for the implementation, which includes immediate and ultimate targets. This strategy should be integrated with the "Comprehensive Development Plan of Baghdad".

- establish a collaborative network between all stakeholders and specialised national and international institutions around the world.

Although Iraq is potentially a rich country, the current crisis demonstrates the need for grants and soft loans, as well as in-kind technical assistance in the short term. The inhabitants need urgent subsidies to improve the physical condition of traditional houses. The central government must cover the upgrading and refurbishing of the infrastructure.

\subsubsection{Associated Guidelines}

- The process of regenerating sustainable conservation should involve active participation and collaboration of the local municipality and community, and other development actors involved in partnership with the programmers and decision-making processes to accommodate the socio-cultural needs of the community. Local governments should help their communities to play a pivotal role in managing and coordinating the regeneration of historic areas in a sustainable manner.

- The priority must be given to empowering the local community in historic areas and strengthening its economy, especially by maximising the utilisation of business resources. The local community should take a lead in addressing some of the economic challenges to promote a healthy economy.

- It is important to bring together professionals and experts from a cross section of Iraq and abroad such as health care, community/development planners, architects and government.

- The immediate action should emphasise careful and sensitive planning in harmony with the overall character of the existing historic area and the gradual process of physical conservation rehabilitation and improvement in the short term. The plan should attract private investment in historic areas and mobilise the drive to economic prosperity.

- The plan should attract investment in the historic areas by promoting the reuse of key buildings as a means of encouraging sustainable regeneration, and maximising the economic contribution of tourism.

- There is immediate opportunity for investment in the river banks as recreational land use and to increase integration between Rusafa and Karkh through building pedestrian bridges. It is necessary to give priority to historic areas in the proposed development plan of Baghdad city and the plan of metro Baghdad.

- It is important to make best use of the waste which is produced, to minimise pollution by reduction, re-use, recovery, and disposal, to ensure that adequate water resources are available to meet consumer's needs, and to establish an environment management system for historic areas.

\section{Conclusion}

The historic areas in Baghdad are suffering from physical deterioration and decay, environmental problems including contaminated water supplies, inadequate waste management, air pollution, and electrical and communications problems.

Sustainable conservation and regeneration must be responsive to a proper understanding of various issues combined with creative approaches based on a mix of economic, social, cultural, physical, and environmental 
initiatives, combined with a holistic urban management. In this context, a sustainable conservation-led regeneration agenda can be defined as a positive tool of planning, and comprehensive vision and action, which has led to the resolution of many conflicting forces in the historic areas. Conservation is a continuous process and must respond to changing conditions. A sustainable conservation-led regeneration plan should be community-led and consensus-based and these citizen-led processes must be complemented by top-down government support.

The central government should empower community-based grassroots organisations for sustainable conservation and regeneration. A key component of this investigation is to stop the clearing of the Kadhimiya historic area immediately and to re-evaluate the value of such areas. The central government should establish an independent Council of Urban Heritage for Historic Areas for regeneration and development. It should stimulate new investment into distressed areas, and develop a tourism industry through introducing a new strategic plan and financial support. To achieve the strategy of immediate sustainable conservation-led regeneration, the government should contribute to such conservation projects and support the council financially. Finally, the central government should set up the formation of an institutional framework, planning development and legislation, and a strengthened regulatory role.

\section{References}

Adams, D. (2004). The changing regulatory environment for speculative house-building and the construction of core competencies for brown field development. Environment and Planning, 36, 601-624. http://dx.doi.org/10.1068/a3557

Al-Akkam, \& Akram J. M. (2011). Urban characteristics: the classification of commercial streets in Baghdad city. Emirates Journal for Engineering Research, 16(2), 1-9. Retrieved from http://www.engg.uaeu.ac.ae/ejer/issues/V16/iss2_16.htm

Al-Akkam, Akram J. M. (2012). Toward environmentally sustainable urban regeneration: a framework for Baghdad city centre. Journal of Sustainable Development, 5(9), 58-74. http://dx.doi.org/10.5539/jsd.v5n9p58

Al-Rahmani, S. F. (1986). Principle for urban renewal in Iraq: a study to develop town planning principles for the renewal of the Iraqi cities with particular reference to Baghdad central area. PhD Thesis, University of Manchester.

Awotona, A. (2008). Rebuilding Sustainable Communities in Iraq: Policies, Programmes and International Perspectives. Cambridge Scholars Publishing.

Baghdad Municipality. (1982). Al Karkh development stage 2, in cooperation with TEST Technical Studies Bureau, Baghdad.

Baghdad Municipality. (2009). Investment opportunities in Baghdad city. Retrieved from http://www.baghdadic.gov.iq/aboutus.aspx

Baghdad Municipality. (2010). The development of Al Rasheed street: Building Al Rasheed for the future, report.

Carmona, M., Heath, T., OC, T., \& Tiesidell, S. (2003). Public Places - Urban spaces: the Dimensions of Urban Design (p. 213). Oxford: Architectural Press.

Cole, R. J. (1999). Building environment assessment methods: clarifying intentions. Building Research \& Information, 27(4-5), 230-246.

Doxiadis, C. (1971). Confessions of a criminal. Ekistics, 191, 249-255.

Drury, P., \& McPherson, A. (2007). Conservation Principles, Policies and Guidance: for the sustainable management of the historic environment. English Heritage.

English Heritage. (1998). Conservation-led Regeneration: The Work of English Heritage. London, English Heritage.

English Heritage. (2004). Heritage Counts: The state of the England's historic environment. London, Heritage counts.

Ercan, Müge Akkar. (2010). Challenges and conflicts in achieving sustainable communities in historic neighbourhoods of Istanbul. Habitat International, 1e12. 
Gore, T., \& Nicholson, D. (1991). Models of the land-development process: a critical review. Environment and Planning A, 23, 706. http://dx.doi.org/10.1068/a230705

Healey, P. (1991). Models of the development process: a review. Journal of Property Research, 8, 224.

Healey, P. (1992). An institutional model of the development process. Journal of Property Research, 9, 33-44. http://dx.doi.org/10.1080/09599919208724049

Healey, P., \& Barrett, S. M. (1990). Structure and agency in land and property development processes: some ideas for research. Urban Studies, 27, 89-104. http://dx.doi.org/10.1080/00420989020080051

Helm, 'Historic environment local management'. (2006). Conservation-led Regeneration Works (p. 31).

House of Commons. (2006). Memorandum submitted by Michael J Coupe. Culture, media and sport - written evidence. London, Culture, media and sport committee publications. P. 2.

Ihsan, F. (1977). Urban Conservation in Iraq. PhD Thesis, University of Sheffield.

Kohler, N. (1999). The relevance of the green building challenge: an observer's perspective. Building Research \& Information, 27(4-5), 309-320.

Lichfield, N. (1968). York: A Study in Conservation. London, HMSO, Appendix G.

Mimoprio, S., \& MacFarlane. (1956). Master Plan for Baghdad. Report, London, p. 38.

Municipality of Baghdad. (2003). Urban development Plan for Baghdad city 2015. Second stage report.

Pearce, G. (1994). Conservation as a component of urban regeneration. Regional Studies, 28, 90.

Pendlebury, J. (2002). Conservation and regeneration: complementary or conflicting processes? The case of Grainger Town, Newcastle upon Tyne. Planning Practice and Research, 17, 145-158. http://dx.doi.org/10.1080/02697450220145913

Pendlebury, J., Townshend, T., \& Gilroy, R. (2004). The conservation of English cultural built heritage: A force for social inclusion? International Journal of Heritage Studies, 10, 11-31. http://dx.doi.org/10.1080/1352725032000194222

Polservice Consulting Engineers. (1974). Kadhimiya Old Quarters, A report submitted to Amanat al-Assima of Baghdad, Warsaw, pp. 14-41.

Roberts, P. (2000). The evolution, definition and purpose of urban regeneration. In P. W. Roberts, \& H. Sykes, (Eds.), Urban Regeneration: a Handbook. Sage: London.

Strange, I., \& Whitney, D. (2003). The changing roles and purposes of heritage conservation in the UK. Planning Practice and Research, 18(19), 229.

UN-HABITAT. (2006-2007). The State of Iraq Cities Report, Cities in Transition. In collaboration with global urban research unite, school of architecture, planning and landscape, Newcastle University, united nations human settlements programme (pp. 95-160).

Worthington, J. (1998). Postscript: conservation through development. In J. Warren, J. Worthington, \& S. Taylor, (Eds.) Context: New Buildings in Historic Settings. Boston: Architectural Press. 